\title{
THE VALUE AND DIFFICULTIES OF LEARNING WITH DIGITAL TECHNOLOGIES AMONG HIGHER EDUCATION STUDENTS IN GHANA
}

\author{
Justice Kofi Armah, \& Duan van der Westhuizen \\ Department of Science and Technology Education, University of Johannesburg (South Africa)
}

\begin{abstract}
Research to determine the relevance (role? importance? value? contribution?) of digital technologies for learning seldom target the students about the value that digital technologies hold for their learning, often disregarding the difficulties students encounter when they learn with these technologies. The Joint Information Systems Committee's (JISC) Higher Education Student Digital Experience insight survey was used to determine the digital experiences of 1,937 students who were enrolled at three dual-mode higher education institutions in Ghana. The results revealed that full-time students valued digital technologies during their learning more than distance learners did. The results further showed that distance learners have more difficulty in managing online information, in comparison to full-time students. The results show that dual-mode institutions in Ghana need to take additional measures to support distance learners with real time instructions to guide students on how to interact with course content. Course content and resource must be delivered in short burst to avoid information overload.
\end{abstract}

Keywords: Digital technology, digital learning, higher education, attitude to technology, Ghana, online learning experiences.

\section{Introduction}

The awareness of and the need for more critical, evaluative and reflective means of utilizing digital technologies for learning dates back in the 1960s. The concept has evolved through three phases - the mastery phase, application phase and the reflective phase. In the mid-1990s - which is the reflective phase - it was realized how ICT could be a force to transform educational pedagogies from passive to active learning. A phenomenon, which was championed during the 1960s in the US and the UK (Knobel, 2008). However, empirical evidence regarding students' value for digital technologies and difficulties of learning with them is sparse especially in sub-Saharan Africa.

Today the use of digital technologies in student learning is becoming an increasingly significant practice with varying claims being made as to how the employment of such technology affects teaching and learning, as well as questions relating to its value in students' lives. For instance, critics of digital technology claims that students are uncomfortable mixing learning with social life on a digital environment (Attia, Baig, Marzouk \& Khan, 2017; Wang, Woo, Quek, Yang, \& Liu, 2012). Contrary to this $21^{\text {st }}$ century teachers and supporters of digital learning assert that new technologies allow students to acquire more knowledge and transfer their skill to different context (Barker \& Gossman, 2013; Deveci, Dalton, Hassan, Amer, \& Cubero, 2018; Dahlstrom, Brooks, Grajek, \& Reeves, 2015; Hamid Waycott, Kurnia \& Chang 2015; Saavedra \& Opfer, 2012). In other words, technology enable students to fit learning into their life more easily (Newman \& Beetham, 2017). In the middle of this argument are those who opine that digital technologies "create opportunities while posing difficulties for students" (Akbar, 2016). It is therefore imperative to investigate thoroughly for suitability of use before integrating any form of technology in a learning activity (Hamid, Waycott, Kurnia, and Chang, 2015). Following this debate, this article might help unravel students' perception on the value and difficulties of learning with the technologies in a Ghanaian higher education setting.

This study aims to explore the value of using digital technologies in teaching and learning as well as the difficulties students face in learning with the technologies particularly in a dual mode institution where the teaching and learning is a blend of face to face teaching with technology used inconsistently both at the distance and regular level. The study adopted JISC higher education students digital experience insight survey to collect data from students in different disciplines to ascertain the value of digital technologies in students learning life as well as the different ways that they struggle with the technologies in their learning. Next is Literature review, methodology use for the study, the results and discussions. Finally, the conclusion of the study will draw on the contributions and suggestion for future study. 


\section{Literature review}

In the advanced countries, students' attitudes towards digital technologies are found to be generally positive (Jewitt, 2012). He alludes that students are enthusiastic about having technology to support learning. They value the convenience and flexibility that technology provides. Most students opine that digital on their course allows them to personalize their learning experience and fit learning into their lives more easily (Barker \& Gossman 2013; Newman \& Beetham, 2017). Others mention that they feel more connected with peers and lectures in a digital environment (Beetham \& Newman, 2017). Students say that digital technologies allow them to experience the technologies as they use them in their everyday life/activities (Anagnostopoulou \& Parmar, 2009). In other words, technology makes learning more relevant, better and understandable to them (Mueller \& Strohmeier, 2010).

Critics of digital in the classroom claim that students' experiences with digital technologies in the classroom causes distractions (Attia, Baig, Marzouk \& Khan, 2017). For instance, a report by ECAR stated that students complained that there has been an increased attempt by some faculty to impose rigid policies on smartphone and tablets use in class (Brooks \& Pomerantz, 2017). "In some cases, faculty ban or discourage devices in classrooms on the basis of research that simply confirms their biases against those digital devices - that they are distracting, that student device usage implies disrespect or a lack of attention, or that students are not taking good notes. This approach can do real, if unintended, harm" (Galanek, Gierdowski, \& Brooks, 2018).

In Ghana digital technologies have invaluable advantages for students. A study by Armah and Westhuizen (2018) revealed that student in Ghana especially distance learners are more receptive to digital learning. Earlier studies however, indicated that Ghanaian students do not respond favorably to digital learning for example online discussion and ill-based activities (Asunka, 2008). Kotoua, Ilkan \& Kilic (2015) empasised that most of the students have negative perception about digital learning environment. He continued that they prefer face- to-face classroom teaching.

\section{Methodology}

The research question posed in this paper is: What are the values of digital technologies in the lives of student and the difficulties of learning with the technology in academic context. To answer this question, we conducted a quantitative study involving final year and postgraduate students in three Ghanaian Universities. University students totaling 1,937 students from different disciplines answered the questionnaire regarding their opinions on the matter. The respondents were made of $57.3 \%$ Male and $42 \%$ female students. Given that digital technology in higher education has become a truly global phenomenon, it is valuable to take a broad view and consider the views of students from different learning modes, 54.3\% of the respondents were fulltime students and $45.7 \%$ were distance learners. Both the fulltime and distance learning students use digital technology to support their learning providing a rich setting in which to explore the phenomena. The students were asked self-reported questions, centered on two main topics: relevance of digital technology in context of their learning; and the difficulties they have learning with those technologies. The survey instrument used consisted of three-point Likert items and was analyzed using the Pearson Chi-square independent test.

\section{Results}

Students were asked how they feel when digital technologies are used in their course. Six positive statements were asked to determine the degree to which they agree with the statements. The percentage summary of their responses revealed that fulltime students $(58,6 \%)$ and slightly less than half of distance learners $(48,9 \%)$ agreed that technology allow them to fit learning into their life more easily. The students agreed that they feel more connected with their fellow students than lectures. Fulltime students $(54,2 \%)$ are more connected to fellow students than distance learners $(41,8 \%)$ when digital technology is used to enhance learning. However, the distance learners are more convinced that technology helps them to connect more with their teachers compared to fulltime students. Students also said they enjoy learning (fulltime students: $69 \%$ distance learners: 54,7\%) and understand things better (fulltime students: 67,7\%, distance learners, 57,9\%) when technology is used on their course. Results of the further analysis is shown in Table 1. 
Table 1. Difference between students positive response to digital on their course.

\begin{tabular}{|c|c|c|c|c|c|c|}
\hline & mode of study & Disagree & Neutral & Agree & $\begin{array}{l}\text { Pearson } \\
\text { Chi- } \\
\text { Square }\end{array}$ & sig \\
\hline \multirow[t]{2}{*}{ I understand things better } & I am a full-time student & 54 & 279 & 707 & \multirow{2}{*}{$50.449^{\mathrm{a}}$} & \multirow{2}{*}{0,000} \\
\hline & I am a distance learner & 127 & 242 & 512 & & \\
\hline \multirow[t]{2}{*}{ I enjoy learning more } & I am a full-time student & 51 & 269 & 720 & \multirow{2}{*}{$59.043^{\mathrm{a}}$} & \multirow{2}{*}{0,000} \\
\hline & I am a distance learner & 117 & 277 & 484 & & \\
\hline \multirow{2}{*}{$\begin{array}{l}\text { I am more independent in } \\
\text { my learning }\end{array}$} & I am a full-time student & 99 & 357 & 581 & \multirow{2}{*}{$22.846^{\mathrm{a}}$} & \multirow[t]{2}{*}{0,000} \\
\hline & I am a distance learner & 148 & 284 & 445 & & \\
\hline \multirow{2}{*}{$\begin{array}{l}\text { I feel more connected with } \\
\text { my lecturers }\end{array}$} & I am a full-time student & 192 & 437 & 411 & \multirow{2}{*}{$4.793^{\mathrm{a}}$} & \multirow{2}{*}{0,091} \\
\hline & I am a distance learner & 185 & 328 & 366 & & \\
\hline \multirow{2}{*}{$\begin{array}{l}\text { I feel more connected with } \\
\text { other learners }\end{array}$} & I am a full-time student & 119 & 382 & 537 & \multirow{2}{*}{$16.938^{\mathrm{a}}$} & \multirow[t]{2}{*}{0,000} \\
\hline & I am a distance learner & 158 & 290 & 426 & & \\
\hline \multirow{2}{*}{$\begin{array}{l}\text { I can fit learning into my } \\
\text { life more easily }\end{array}$} & I am a full-time student & 92 & 334 & 612 & \multirow{2}{*}{$41.173^{\mathrm{a}}$} & \multirow{2}{*}{0,000} \\
\hline & I am a distance learner & 162 & 276 & 433 & & \\
\hline
\end{tabular}

Further analysis using the Pearson-Chi-square of independent test revealed (see table 1) a significant difference in the value students attach to digital on course by fulltime students compared to distance learners. Fulltime students were more likely to understand things better $X^{2}(2,1921)=50.449$, $p=0,000$, enjoy learning with technology $X^{2}(2, N=1918)=59.043, p=0,000$, more independent in their learning $\mathrm{X}^{2}(2, \mathrm{~N}=1914)=22.846, \mathrm{p}=0,000$, feel more connected with other learners $\mathrm{X}^{2}(2, \mathrm{~N}=1912)=16.938, \mathrm{p}=0,000$ and are able to fit learning into their life more easily $\mathrm{X}^{2}(2, \mathrm{~N}=1909)=41.173, \mathrm{p}=0,000$ compared to their distance learning counterparts

No statistically significant difference was found in mode of study and students-lecture connectedness when digital technology is used on course, $\mathrm{X} 2(2, \mathrm{~N}=1919)=4.793, \mathrm{p}=0,091$.

Also, six negatives (difficulties of digital learning) statements were asked about the value of learning with technology. More than half of the students disagreed that: they are less likely to attend class when digital technology is used on their course (fulltime students: $56,3 \%$, distance learners: $55,6 \%$ ). Some $55.5 \%$ of fulltime students and $54 \%$ of distance learners disagreed that digital on their course made them more isolated. $52.2 \%$ of fulltime students and $52.7 \%$ of distance learners disagreed that they are more easily distracted with digital on their course. Only $16.5 \%$ of fulltime students and $15.1 \%$ of distance learners agreed that they are likely to skip classes when digital technology is fully integrated on their course.

The chi-square analysis (see table 2) revealed that students equally did not have difficulty learning with technology. Only distance learners are more likely to face slight problem with managing information when digital technology is used on their course compared to fulltime students, $\mathrm{X}^{2}(2, \mathrm{~N}=1920)=7.362$, $\mathrm{p}=0.025$. The Bonferroni adjustment test indicated that greater percentage of distance learners $(51,1 \%$, this is above the average percentage of 45,8\%) however the proportion was not significant (adjusted residual $=2.1, \mathrm{p}=0,040$ ).

Table 2. Negative attitude toward digital technology on course.

\begin{tabular}{|c|c|c|c|c|c|c|}
\hline & mode of study & Disagree & Neutral & Agree & $\begin{array}{l}\text { Pearson } \\
\text { Chi- } \\
\text { Square }\end{array}$ & sig \\
\hline \multirow{2}{*}{$\begin{array}{l}\text { I am more easily } \\
\text { distracted }\end{array}$} & I am a full-time student & 545 & 289 & 206 & \multirow[t]{2}{*}{$1.762^{\mathrm{a}}$} & \multirow[t]{2}{*}{0,414} \\
\hline & I am a distance learner & 466 & 260 & 155 & & \\
\hline \multirow{2}{*}{$\begin{array}{l}\text { I find it harder to all } \\
\text { information }\end{array}$} & I am a full-time student & 517 & 369 & 154 & \multirow[t]{2}{*}{$5.677^{\mathrm{a}}$} & \multirow[t]{2}{*}{0,059} \\
\hline & I am a distance learner & 398 & 321 & 161 & & \\
\hline \multirow[t]{2}{*}{ I feel more isolated } & I am a full-time student & 579 & 322 & 136 & \multirow[t]{2}{*}{$4.703^{\mathrm{a}}$} & \multirow[t]{2}{*}{0,095} \\
\hline & I am a distance learner & 478 & 253 & 145 & & \\
\hline \multirow{2}{*}{$\begin{array}{l}\text { I find it harder to } \\
\text { motivation }\end{array}$} & I am a full-time student & 588 & 316 & 136 & \multirow[t]{2}{*}{$7.362^{\mathrm{a}}$} & \multirow[t]{2}{*}{0,025} \\
\hline & I am a distance learner & 439 & 300 & 133 & & \\
\hline \multirow{2}{*}{$\begin{array}{l}\text { I am less likely to } \\
\text { attend lectures }\end{array}$} & I am a full-time student & 588 & 278 & 172 & \multirow[t]{2}{*}{$1.033^{\mathrm{a}}$} & \multirow[t]{2}{*}{0,597} \\
\hline & I am a distance learner & 492 & 250 & 134 & & \\
\hline
\end{tabular}

\section{Discussion}

With regard to the value students have for digital learning, it was identified that more fulltime students value digital learning compared to distance learners. For example, significant proportion fulltime students opined that digital on course makes them more independent learners. They also agreed more that the enjoy learning, understand things better and are able to fit learning into their life when digital technology 
is used on their course. This suggest that distance learners in Ghana do not respond favorably to digital learning. Wolcott (2003) blame distance learners' gray attitude to digital learning on lecturers. Some lectures in dual mode institutions who may have the pedagogical and technological skill to integrate the technology view the distance learning department as part of assignments and ultimate whilst the majority sit on the wall to watch. In other words, the distance sector lacks the qualified staff to integrated technology into the learning activities. Most institutions engage the services of instructors / tutors outside, sometimes compromising to instructors who may not have the skills of digital integration. Such situations put the effectiveness of distance learning in question for the promotion of equivalency (Wolcott \& Betts, 2007).

It was also identified that slightly significant proportion of distance learners find it more difficult to manage all the information when digital technology is used on their course. They therefore prefer the institutions to continue to support them with face-to-face lectures. This finding confirms earlier study by Ofted (2009) which stated the use of digital on course will not stop students from attending classes / lectures. It also contradicts with Boyles et al (2008) suggestion that digital on course are a danger and as well discourages and ceases students from attending lectures. The results show that the students', generally, value digital on their course. They (students) value the convenience and flexibility that technology provides and therefore are enthusiastic about having digital technology to support their learning as suggested by Barker and Gossman 2013; Beetham \& Newman, 2017; Jewitt, 2012). The onus lies on instructors especially in the distance sector to effectively integrate the technology in the subject disciplines.

\section{Conclusion}

The study explored the value of digital technologies in students learning as well as the difficulties they face when learning with the technologies. Generally, both group of students are self-motivated and do not feel distracted or isolated when digital technology is integrated into their learning. However, fulltime students are more likely to find technology useful in their learning as compared to distance learners. These findings indicate that although students are technology inclined, fulltime students in Ghana value the use of technology to support learning compared to distance learners and are also less likely to find difficulty learning with technology. The results also indicate that dual mode institutions should continue to support distance learners with face-to-face session with the integration of technology. We also recommend the use real-time instruction (e.g. video conferencing) to support students' on how to interact with course content and resources. This will help the student students to feel connected with the course.

\section{References}

Akbar, M. (2016). Digital technology shaping teaching practices in higher education. Frontiers in ICT, 3, 1 .

Armah \& Westhuizen (2018). Embedding digital capiability development into the curriculum in ghana: not there yet, Towards Effective Teaching and Meaningful Learning in Mathematics, Science and Technology Education: $9^{\text {th }}$ Annual UNISA ISTE Conference on Mathematics Science and Technology Education (pp. 307-314). Mpumalanga, South Africa: University of South Africa.

Attia, N. A., Baig, L., Marzouk, Y. I., \& Khan, A. (2017). The potential effect of technology and distractions on undergraduate students' concentration. Pakistan journal of medical sciences, 33(4), 860.

Asunka, S. (2008). Online learning in higher education in Sub-Saharan Africa: Ghanaian University students' experiences and perceptions. The International Review of Research in Open and Distributed Learning, 9(3).

Barker, J., \& Gossman, P. (2013). The learning impact of a virtual learning environment: students' views. Teacher Education Advancement Network Journal (TEAN), 5(2), 19-38.

Brooks, D. C., \& Pomerantz, J. (2017). ECAR Study of Undergraduate Students and Information Technology, 2017. EDUCAUSE.

Dahlstrom, E., Books, D. B., Grajek, S., \& Reeves, J. (2015). ECAR Study of Students and Information Technology, 2015. Research report. Louisville, CO: ECAR, December 2015.

Deveci, T., Dalton, D., Hassan, A., Amer, S. T., \& Cubero, S. (2018). Project-X: An Initiative to Increase Student Engagement through Laptops. Contemporary Educational Technology, 9(1), 1-21.

Galanck, J. D., Gierdowski D. C., \& Brooks D. C. (2018) ECAR Study of Undergraduate Students and Information Technology, 2018. Research report. Louisville, CO: ECAR.

Hamid, S., Waycott, J., Kurnia, S., \& Chang, S. (2015). Understanding students' perceptions of the benefits of online social networking use for teaching and learning. The Internet and Higher Education, 26, $1-9$. 
Jewitt, K. (2012). Technology Solutions for Student Learning: Research Study into the experiences and expectations of digital technology by students at PROCAT. Retrieved December 16, 2018 from http://procatdigital.co.uk/technology-solutions-for-student-learning/

Knobel, M. (2008). Digital literacies: Concepts, policies and practices (Vol. 30). Peter Lang.

Kotoua, S., Ilkan, M., \& Kilic, H. (2015). The growing of online Education in sub Saharan Africa: Case study Ghana. Procedia-Social and Behavioral Sciences, 191, 2406-2411.

Newman, T., \& Beetham, H. (2017). Student digital experience tracker 2017: the voice of 22,000 UK learners. JISC

Newman, T., Beetham, H., \& Knight, S. (2018). Digital experience insights survey 2018: findings from students in UK further and higher education [Ebook]. UK: JISC. Retrieved from http://repository.jisc.ac.uk/6967/1/Digital_experience_insights_survey_2018.pdf

Great Britain. Office for Standards in Education (England)(Ofsted). (2009). Virtual learning environments: An evaluation of their development in a sample of educational settings. (ref:070251). London: Ofsted

Great Britain. Office for Standards in Education (England)(Ofsted). (2009). Virtual learning environments: An evaluation of their development in a sample of educational settings.

Saavedra, A. R., \& Opfer, V. D. (2012). Learning 21st-century skills requires 21 st-century teaching. Phi Delta Kappan, 94(2), 8-13.

Wang, Q., Woo, H. L., Quek, C. L., Yang, Y., \& Liu, M. (2012). Using the Facebook group as a learning management system: An exploratory study. British Journal of Educational Technology, 43(3), 428-438.

Wolcott, L. L. (2003). Dynamics of faculty participation in distance education: Motivations, incentives, and rewards. Handbook of distance education, 549-565.

Wolcott, L., \& Betts, K. (1999). Whats in it for me. Incentives for faculty. 